\title{
Lived Stories of Mid-Career Teachers: Their Struggles with Millennial Learners in the Philippines
}

\author{
Evelyn B. Aguirre \\ Leyte Normal University, \\ Tacloban City, Leyte, Philippines \\ Solomon D. Faller Jr. \\ Leyte Normal University, \\ Tacloban City, Leyte, Philippines
}

Doi: 10.2478/jesr-2018-0005

\begin{abstract}
This study aimed to explore the teaching-learning congruence between mid-career teachers and millennial learners which remains a global challenge. After 15-30 years of teaching, they face issues on self-absorption with great desire to develop themselves instead of mentoring others. In the Philippines, they resort to printed learning materials, while the millennials are highly addicted to technology and ecopies. Self-reflected learning is dominant in mid-career teachers, while collaborative learning works well with millennial learners. The said divide in their teaching and learning strategies results to constant struggles among mid-career teachers. In Australia and some countries, there is scanty literature on midcareer teachers. This phenomenological case study in a Philippine teaching university unraveled their day-to-day struggles as they coped and bridged the teaching-learning divide. Results can usher in a paradigm shift in mid-career teachers teaching as well as produce policy enablers with capacity building to manage millennials as top priority in the Philippines, in Asia and abroad.
\end{abstract}

Keywords: collaborative learning, phenomenological, mid-career teachers, millennial learners, teaching-learning

\section{Introduction}

In the majority of the Asian Education scenario, teachers both in the basic education and tertiary level grow old in contrast with the high attrition rate of beginning teachers in the first world countries. They never stop teaching up until their retirement. With almost 3-4 long decades of teaching the said teachers in the ASEAN countries encounter diverse generations of learners. Nowadays, the most widely talked about generation of learners in Asia, in Europe and the USA is the generation $\mathbf{M}$ learners or otherwise known as millennial learners, or the Echoboomers or Nexters. They are the learners born in or after the year 1992 (McGlynn, 2005).

As reported by (McGlynn 2005) these group of students comprise 70 or 80 million people or about 30 percent of the population in America. The millennial learners are the children of the babyboomer generation. These set of learners have peculiar learning styles from former students and from older classmates.

The age differentiated learning styles of the millennial generation is a complex factor that senior teachers and teachers who are in the middle of their careers must understand in detail in order to become effective teachers. The latter are exposed to a totally different home as well as learning environment and possess totally different learning styles, thus, different ways of thinking 
and learning from the millennial learners that they cater too. Consequently, a counterproductive teaching-learning process occurs. While the former resort to self-reflected learning the latter prefers collaborative learning (Bart, 2011). The so-called mid-career teachers and senior teachers who are relegated the crucial aspect of inculcating learning among a totally different set of learners with study and learning habits apart from their own, suffer innumerable struggles and problems that is described in this study with the goal of arriving at some useful insights and implications of how teachers of millennial students could cope and capacitate themselves to bridge the knowledge and skills divide between the two important players in instruction, thereby resulting to teaching and learning congruence as well as high learning performance among learners in the millennial classrooms.

\section{Review of Literature}

\subsection{Characteristics of Millennial Learners}

Millennial learners are the generation who are labelled with many names such as Generation $Y$, the Net Generation, the Next generation and most commonly the millennial generation. This generation composes children born between 1982-1995. Their parents have kept their children so busy by exposing them to sports, music lessons, club meetings, youth group activities and in part-time jobs. Millennial are called the Net Generation because they spend many hours on the computer, often the Internet, interacting with peers, doing school work, playing computer games, shopping and otherwise entertaining themselves. They are driven by instant gratification in an informal and stimulating environments and they are more comfortable with casual and friendly relationships with teachers (Sanchez, 2016).

Highly self-confident, extremely social, technologically sophisticated, action bent, goal oriented and adheres to collaborative and teamwork brought about by close family orientedness, rich school experiences along with their heavy mass media exposure. Because of so much activity in their lives as well as constant socializing with friends and family they have less inclined to engage in self-reflection and self-examination. Thus, they emerge as impatient, demanding, stressed out, sheltered, brand oriented, materialistic and self-centered. They want to be cared for thus, they stay close to their parents and turn to them for help. They are used to their parents hovering over them to ensure their well-being and competitive advantage in life (Stanford University).

The Millennial Cohort, according to McGlynn (2005) study, it is a must to remember that strengths of the millennials as a distinct generation of learners include goal oriented, positive attitudes, multi-tasking and subscription to collaboration and teamwork. Furthermore, McGlynn (2005) outlines some characteristics that represents to many of the millennial cohort as being students who grew up in a time of economic security; they are the most protected generation in terms of government regulations or consumer safety. They are used to being indulged in childrearing and thus experts' consultation in decision making from their parents. Because of over indulgence from their parents' millennial expert individual attention, extra help and other institutional resources to be provided in order to help them with any difficulties they meet in the process of learning.

Entitled, narcissistic, lazy, uncommitted, educated, tech savvy, diverse and socially resourceful is how Daniel (2015) described the millennial learner generation.

Flaherty (2013) narrated that neuroscientists stressed that history has shaped the cognitive functioning of the millennial generation, strengthening certain neural pathways through repeated use and weakening others through infrequent. Millennial learning is often heard saying "I don't like reading" or I can't text and listen to you at the same time, reiterating the multi-tasking brain of the millennial learners.

\subsection{How Should Teachers Engage and Attract Millennial Learners}

In conducting a study on Millennials Ideal Learning environment, Bart (2011) outlined several ways 
and means to engage millennial students: 1 . Millennials prefer a variety of active Learning Methods. The elements of their learning environment are: less lecture, use of multi-media, and peer collaboration. 2. Millennials work well when applying new learned information to real life situations. Hence, teachers are challenged to connect course content to the current culture and make learning outcomes. 3. Millennials responds well for non-authoritarian teaching manner since they are highly rational. Teachers there should provide them with a rationale for specific policies and assignments. 4. Millennials prefer a less formal learning environment when they can informally interact with the professor and one another. 5. Millennials are very relational. Thus, Professors must connect with them on a personal level. They are motivated to pursue learning outcomes when dealt with in a more caring manner.

For Millennials, McGlynn (2005) suggest that success learning means engaging them with cooperative learning exercises, empowering them to be decision makers in the course and getting them to analyze their own learning strategies. As suggested by Bart (2011), to effectively engage the millennials, the approach should be research-based, relevant, with clear rationale, relaxed and good rapport.

Technology already serves as an extraordinary tool to shape and enhance the learning environment and along with equipment, digital literacy skills are absolutely necessary to ensure the technology is used to supplement-and not substitute for-high-quality instructional methods (International Education Advisory Board). It has suggested practical views to effectively engage the millennial learners in the classroom. One of the pre-requisites is enough preparation of ICT equipments and tools that can be used for teaching the students. Beyond the presence of tools and equipment inside the classrooms is also a curricular design that encourage a collaborative learning style and learner focus. Added to it is the question of how prepared and fit the teachers are as they immerge into this teaching-learning mode which may require certification of both the teachers and students on the use of ICT for instruction.

Elucidating on the relationship of Millennial Students and Middle-aged faculty, Flaherty (2013) narrated that millennial classes revolve around 10-15 minute chunks of fast-paced activity designed to address students with short attention spans who are easily bored. The extended availability via electronic media into the evenings and weekends targets the preference for constant mediated face to face connectivity. Flaherty adopted their practices as to achieve a learner-centered environment which empirically has been proven to work well with millennial learners.

Forwarding useful insights in teaching millennial students Leslie Owen Wilson recognized and came to realize that Professorship has changed - no longer an expert, now simply a person with expertise. The millennials want to have some control of aspects of the class and their educational directions and experiences. They certainly are looking for everyday heroes and role models that are realistic. To save time to finish learning deliverable millennials want prototypes, samples and examples. They have little tolerance for experiences that may hamper their progression toward some goal.

\section{Methodology}

\subsection{Research Design}

A phenomenological inquiry method particularly the case study approach was used in this study in exploring and documenting the real-life stories of the mid-career teachers in teaching the millennial learners. Phenomenology is a sober reflection on the lived experience of human existence that must be thoughtful, and as much as possible, free from theoretical, prejudicial and suppositional intoxications (van Manen, 2007). Lester (1999) explained the purpose of a phenomenological approach in qualitative research which is to illuminate a given phenomenon and on how it is perceived by the people who are involved in the situation. For this study, it was carried over through the conduct of a focus group discussion and interviews with the mid-career teachers. This method gave the authors of this study a leeway for an exhaustive exploration of the actual experiences of the mid-career teachers in their day-to-day routines in school with the millennial students. 


\subsection{Research Setting}

This study took place in a government-operated Higher Education Institution (HEI) teaching training university located in Tacloban City, Philippines. The university is under the supervision of the Commission on Higher Education (CHED), the government's agency in-charge to oversee the operation of all the state, universities and colleges in the country. The university was first established in the year 1921 as a 2-year teacher-training school, and after 96 years of its existence, in 1995 it was converted into a university. It always upholds its mandate to produce top performing professionals equipped to engage on knowledge and technology production, which are necessary factors to develop a sustainable society. The university is categorized as a medium-size with an average enrollees between 6,500 to 7,000 students every school year spread in the 35 different curricular programs that are offered by the university. As a teacher-training university, the education department holds the highest number of students which is more or less half of the total population. The school is the highest producer and supplier of high quality graduates and full-pledge teachers and hospitality management that are being deployed for work all over the Eastern Visayas region and in other parts of the country.

\subsection{Research Participants}

The data for this study were reliably gathered from the mid-career teachers who were purposively identified and selected for this purpose. The participants were composed of 1 participant from the Science unit, 1 from the Tourism, Hotel and Restaurant Management unit, 1 from the Filipino unit, 1 from the Social Science unit, and 3 from the Education department of the university. The backgrounds and specializations of the mid-career teachers are varied that include pure science, hospitality management, education, social science, and Filipino. The study is highly dependent on the experiences that would be shared by the mid-career teachers as participants of this study, and so one of the criteria that was considered by the authors in the selection of respondents was the number of years of actual teaching inside and outside the university. The number of years of teaching of the mid-career teachers who were the participants of this study is between 15 to 25 . This was the basis for their responses that highlighted their struggles and experiences on their dayto-day encounter with the millennial learners.

The authors have complied and strictly observed the ethical mandate in conducting researches by maintaining the anonymity of the participants. This study has made sure that the verbatim responses stated herein are non-traceable as to who were the specific authors of such statements. The raw data, documentation and audio tapes of the different conversations and discussions between the authors and the participants were kept with utmost care and confidentiality with the assurance that all these were utilized for this research only.

Table: Description of Participants

\begin{tabular}{lccc}
\hline Respondents & Age & No. of years of teaching experience & Academic unit assignment \\
\hline $\begin{array}{l}\text { Mid-career teacher 1 } \\
\text { (GNV) }\end{array}$ & 51 & 21 years & Science Unit \\
\hline $\begin{array}{l}\text { Mid-career teacher 2 } \\
\text { (EVS) }\end{array}$ & 46 & 15 years & HRM/THRM Unit \\
\hline $\begin{array}{l}\text { Mid-career teacher } 3 \\
\text { (JGE) }\end{array}$ & 47 & 22 years & Filipino Unit \\
\hline $\begin{array}{l}\text { Mid-career teacher 4 } \\
\text { (LGF) }\end{array}$ & 47 & 25 years & Education Unit \\
\hline $\begin{array}{l}\text { Mid-career teacher 5 } \\
\text { (PCC) }\end{array}$ & 42 & 17 years & Social Science Unit \\
\hline $\begin{array}{l}\text { Mid-career teacher 6 } \\
\text { (LMR) }\end{array}$ & 41 & 19 years & Education Unit \\
\hline $\begin{array}{l}\text { Mid-career teacher 7 } \\
\text { (JAT) }\end{array}$ & 49 & 26 years & Education Unit \\
\hline
\end{tabular}




\subsection{Data Collection Method}

The data for this study were collected through the conduct of focus group discussion which were participated by the mid-career teachers that were purposively selected from the list of the faculty members of the university. The FGD has proceeded using the guide questions which was crafted by the authors, and the participants were made to comment and react on the following:

1. The number of years of teaching in the university.

2. Adjustments made as mid-career teacher in the university.

3. Difficulties, problems and challenges experienced by the mid-career teachers with the students and how do they manage to address such problems.

4. Do you experience difficulties and problems with the students? Can you describe to us what are those problems and difficulties? How do you manage to solve them?

5. Factors that contributed to the struggles and challenges as mid-career teachers.

6. Coping with the struggles and challenges as mid-career teachers in the university and what made them cope with such struggles and challenges along establishing interpersonal relations with neophyte teachers; peers and supervisor, lesson planning and class preparation; classroom management and instilling class discipline; actual classroom teaching; assessing student performance.

The participants were informed about the research and their consent to be part of it was first solicited. After their approval they were invited to a focus group discussion which was held in a very comfortable venue, free from destruction and any other unnecessary intervening factors that might affect the data gathering procedure. They were made comfortable first by the authors, after which they were oriented about the study, its focus and purpose were emphasized and discussed to ensure the correctness of the responses of the participants.

For logical and smooth discussion, the questions which were included in the guide questionnaire were asked one at a time and the participants were made to say their answers and views freely about the questions stipulated earlier in the discussion. The facilitators proceeded with the answering and discussion of one question to the rest of the questions. The participants were requested to elaborate and explain when the facilitators felt the need to expound and clarify their answers and views. To capture the entire conversation, a double recording was adapted using an audio recorder and at the same a running detailed documentation by the authors. Careful transcription of the recordings was personally facilitated by the authors in order to ensure the accuracy of the transcribed data.

\subsection{Data Analysis}

The authors of this study have found the Colaizzi method as the most appropriate approach to analyze the data since it is phenomenological. This phenomenological method of inquiry stresses on issues of rigors and trustworthiness in order to arrive at a decision relative to the themes of lived experiences of people (Sanders, 2003). The method involves seven important steps that should be observed in analyzing the qualitative data.

(1) Thorough reading and understanding of the transcribed data that described the lived experiences of the respondents;

(2) Formulating the significant statements based on the carefully transcribed responses of the respondents;

(3) Crafting the formulated meaning out of the formulated significant statements;

(4) Formulating the themes based on the meanings and organizing them into cluster;

(5) Describing the themes extensively and comprehensively;

(6) Generating the structure of the phenomenon under study;

(7) Validating the results of the analysis with the perspectives of the participants

\section{Results and Discussion}

The themes that were formulated based on the result of the analysis using the Colaizzi method is 
presented in this section. The major classifications of the themes are (1) Struggles and problems in teaching millennial learners emanating from the teachers; (2) Struggles and problems in teaching millennial learners emanating from the learners themselves; (3) External Sources of Problems in Teaching the Millennials; and (4) Coping Strategies of Mid-Career Teachers in Teaching Millennials.

Today's learning setting has significantly changed in the advent of this generation's millennial leaners as they have started shaping the new system of educational systems. Curricula evolve, and new teaching methodologies are developed to reach this generation, which spends as much time stimulated by digital media as it does in school and as teachers work to engage and educate this generation of millennial students, they face with challenges (International Education Advisory Board). This particular study has explored the actual challenges of these millennial students that were caused from the disposition of the teachers.

\subsection{Mid-career Teachers' Struggles Within Themselves in Teaching Millennials}

\subsubsection{Theme 1. Deflation of teacher's Ego and Self-esteem}

Teachers were caught in a situation where they were forced to shift their standpoint when at first they were the ones who are expected to mentor, but at this point they were the ones receiving inputs from the students. Millennial are adventurous in learning new things and so in most cases they discovered many things in their own ways and in many cases the teachers have limited or totally have no knowledge about it. In this study, the mid-career teachers have encountered this experience wherein they need to be taught on somethings by their students.

"I gave my students a sample problem in Physics, I was surprised the way my students have solved it and their approach was different but the answer was correct. They told me that they were able to ask for help from a Professor abroad through the use of Facebook"

\subsubsection{Theme 2. Inadequacy and Lack of Computer Skills and Knowledge}

Millennials are wanting more from their Professors and they described their professors as disconnected, not really teaching anything, confused, disengaging entertainers, unable to use technology, and not trained in education and who had spent a considerable amount of time discussing the frustrations of professors who merely read off of the Power Points, (Toothaker, 2014)

Mid-career teachers in this present times have confirmed that they really lack knowledge on the use of available technologies and are being utilized by the millennial learners. Many of our midcareer teachers were educated during the time when the use of computer was still in their infancy stage and so their exposure was very limited and some maybe practically have no experience of manipulating such equipments. This is one thing that the teachers have to cope-up, to learn fast and be at par more or less with their learners.

"so it's really accepted - the term they are really 'techy' while us, we still dwell on ballpen, pencil and paper"

"these are really very challenging for the teachers with average knowledge on the latest technology, mastery of the different applications is very important, because as of now it is not really practical that we solely rely on books as references because we will be left behind"

\subsubsection{Theme 3. Scarce Knowledge and Skills in Computer Assisted Preparation and Use of Teaching and Learning Materials}

Today's educators are somewhat reluctant to adopt new technology too quickly, some educators feel intimidated by students' knowledge of tools they do not understand (International Education Advisory Board). Millennials want assignments that are more creative than the typical 10-page final 
paper, millennials seem to be more experiential and exploratory learners, so they really seem to benefit from the personalization and customization of assignments (Novotney, 2010).

\begin{abstract}
"majority of my students could come-up with very nice powerpoint presentations, with hyperlinks and animations, as a teacher there are times that I am embarrassed because I do not know these things"
\end{abstract}

"during the first few weeks, I had my powerpoint presentations, and they were just very simple without animations, and I was ashamed to use it in my teaching and so I need to improve myself in terms of using this technology"

\title{
4.1.4 Theme 4. Detrimental Increment in School and Office Hours due to Inefficient Technology System
}

The mid-career teachers have shared that they really lack time for the preparation of individual learning materials and in conceptualizing activity-centered activities for the students. They looked at this strategy to address students' boredom, and lack of enthusiasm to learn inside the classroom. They also expressed about their struggles as far as time allocation is concerned for the checking of outputs in order to detect and prevent conspiracy which sometimes a practice among students.

"in checking the activities and outputs of the students, I have to do it one by one and then return it to the students, it was very tasking and burdensome especially for a big class and it consumes most of our time"

"for example, I required by students a thought paper and then it's a big class with more or less 50 students, so it's really a very heavy task for teachers and very tiring"

\subsubsection{Theme 5. Non-mastery of Technology Driven Teaching and Learning Strategies}

The struggles of mid-career teachers in disposing their function may emanate also from the learners themselves. It is not surprising because of the many differences between them, it would be a challenging task for these teachers from appreciating the behavior of millennial learners to the actual teaching and learning experiences. According to Nevid (2011), as instructors, we may have a difficult time understanding our millennial students and we may even think of them as an alien species. The succeeding discussions pertains to the struggles that have emanated from the learners as experienced by the mid-career teachers.

"there's a problem regarding instilling classroom discipline, you should not have very lengthy discussions because they have short span of listening, you need to have activities for students to participate, otherwise they will just be playing and manipulating their cellphones"

The above verbatim statement of mid-career teachers, suggests that they need to think of teaching techniques and style that would fit and suitable with the learning style and characteristics of millennial learners. This would entail recalibration of the curriculum and syllabi by the teacher specifically the integration on the use of technology in teaching strategies and in the actual delivery of topics and lessons in class.

\subsection{Mid-career Teachers' Struggles Rooting from the Millennial Characteristics}

\subsubsection{Theme 1. Impatience and Aggressiveness of the Millennials}

This generation is motivated, goal-oriented, assertive, confident and they want to make a difference, civic-minded and value service learning and volunteerism. They believe college will help them get a great start in life and expect to advance rapidly in the workplace (Division of Student Services, California State University, 2008)

"the students are impatient, they want things done quickly and the classes to end immediately, they 
do not want to write and they just use their cellphones to take pictures of the topics that are discussed in class"

\subsubsection{Theme 2. Retrogression and Erosion of Creative and Critical Thinking of Millennials}

The easy access to technology (e.g. internet, social media) by the students has made them dependent on it for their ability to learn on something. According to the teachers, this has eroded the creativeness, the critical and analytical thinking skills of the students. Typical example to this is the disinterest of students to take notes when the teacher is discussing the lessons and also the dislike to read especially lengthy texts and discussions. Millennials have shorter attention span and they prefer interactive, experiential collaborative learning and they are comfortable with technology (Sanchez, 2016).

"only one student will do the copying of lessons and then this will be passed to the rest of students using facebook"

"another that I have observed with my students, that they devote lesser time in reading, what they like most is doing cooperative learning activities"

Teachers have observed that millennial learners have shifted and have adapted the shortcut way of learning things using application softwares and technologies that are available to them. In the 2007 study, $87.1 \%$ of Millennial students used Google frequently, and $35.1 \%$ thought Google a more useful tool than those provided by the library and $51 \%$ frequently used Wikipedia for assignments. (Nicholas, 2008)

"they want to use video and if you assign topic to them, they are not going to read that on books, what they usually do is watch video, so if you will ask them about the details, they cannot explain"

The students at present are having difficulty following or making extended analytical arguments and they tend to use easily obtained, superficial and unreliable online sources as a way of satisfying minimal requirements rather than seeking more authoritative sources in the library and online. Without much evidence at their disposal, they tend to fall back on their feelings, which are personal and, they think, beyond questioning (Benton, 2008).

"I asked my students to write a detailed lesson plan, so I found out that there are times that they are really lazy in writing, they write in English is a shortcut manner, and I have also observed the spelling are erroneous and they are fond of using the "text style.".

\subsubsection{Theme 3. Promotion and Development of the Culture of Collusion and Cheat}

The dynamics of students in class and because of the readily available technologies that are at hand by the students have made them susceptible to some malpractices and sometimes they are unmindful of committing violations. Teachers have to deal this problem of collusion among students in complying with their requirements and assignments in class. Below are some of the actual encounter of the mid-career teachers on students who have committed such acts.

"I have tried using the email for my students to submit their class requirement, and I have discovered that only one student has complied with it, and what the rest of the students did was simply changed the name and submit the requirement". And so, I required them to submit also the hard copy because at least they have exerted effort to write and copy the requirement"

"I required my students for a write-up, and there were times that the first paragraph which was written by one student also appeared in the last paragraph of the output of the other student and that is their style"

\subsubsection{Theme 4. Defocused Studies Among Millennial}

The teaching - learning dynamics by the teacher and students is also being challenged in terms of 
getting the focus of the students and the right attention for them to learn the things that are being shared in class. These gadgets especially cellphones wherein almost all of the students owned such device, compete with the teacher's discussion inside the classroom and this has been considered as one of the common disturbance among students. They described their attendance as they should always there, classroom time is mandatory, and present even though they attend class, they go on to describe being mentally dislocated (Toothaker, 2014).

"when they arrived in the classroom, first period 7:30 in the morning some students are already sleepy"

\subsection{External Sources of Problems in Teaching the Millennials}

\subsubsection{Theme 1. Infrastructure Technology Deficient System}

There is a need for the mid-career teachers to cope in terms of the use of technology in the discharge of their functions as teachers of the millennial learners. They themselves have openly recognized and accepted this fact that they can be more effective teachers if equipped with the know-how of using the available technologies and be able to integrate this into the teachinglearning processes. In this case, the availability of these facilities and equipments to teachers would ease them in their struggles, however, this is not the case in the university where these mid-career teachers are presently teaching.

"our internet connection is weak and so if you want to use it you have to come to school early at around 6:00 in the morning because at 7:00 it is already difficult to access."

\subsubsection{Theme 2. Large Millennial Classes}

Typical to the university where this study was conducted are classes with 40 students or even more than 50. And with the implementation of the Outcomes-Based Education curriculum higher education, this has also poses another struggle and challenge for the teachers. Individual outputs of students need to be checked by the teacher which eats up a big part of their time.

\subsection{Coping Strategies of Mid-Career Teachers in Teaching Millennials}

The traditional lecture mode of instruction may not be dead, but it does require retooling in this age of limited attention spans and increased emphasis on student engagement (Nevid, 2008). The midcareer teacher participants of this study have shared their practical points of view of coping with the situations that they are in at present - teachers of the uniquely characterized millennial students.

\subsubsection{Theme 1. Fostering Friendlier Relations with Millennials}

Millennials are extremely relational therefore building good rapport with them is effective in engaging them and they appreciate it when professors show that same interest, and they seem to be more willing to pursue learning outcomes when instructors connect with them on a personal level (Bart, 2011).

\subsubsection{Theme 2. Requirement of Technology Generated Learning Materials for Future Use of the Teacher}

The purpose of using of technology such as the use of power point, course management systems, student response systems, podcasting and online learning systems is to enhance good teaching and not to replace good teaching (Nevid, 2011).

"In my case, I asked a copy of the presentation from the students, so that next time, I can use the materials in my class and in terms of animations and the kind of materials, these are really good" 


\subsubsection{Theme 3. Participation in Training on Technology-based and Computer-aided Instruction}

Phillips and Trainor (2014) have shared the flipped classroom approach which generally involves the preparation short audio or video lectures, which students review before coming to class. Since students perform the information gathering portion of learning outside the classroom, professors are able to devote class-time to the application of that knowledge using active learning techniques. Millennials prefer classroom, online and blended learning experiences (Sandeen, 2008), and respond well to feedback and learning technologies when used to support learning (Prensky, 2013). These are accepted facts by the teachers as evidenced by their responses in the study.

"actually this technology can just be learned, but because we are attached to other activities, it's also good if we will be exposed to a formal training, so that it's a sort of retooling"

"the use of the different applications and the downloading of documents, teachers must be trained on it, not really a formal training, even one or two hour sessions would be enough".

\subsubsection{Theme 4. Learning Side by Side and Receiving Technology Mentorship from the Millennials.}

Beard et. al (2007) argues that this generation of students has been technologically enabled and shaped by access to world and cultural events at the touch of a button and it is in the best interest of students, faculty and employers that the characteristics of this generation be considered in determining the best way to shape their capabilities to maximize their earning and productivity potential.

"These millennial learners are very challenging on my part especially my Bachelor of Science in Secondary Education (BSED) students. They are very creative and very resourceful. There were times that I was surprised and amazed of what they are presenting in class and the manner of doing things. Sometimes I am forced to surf and search on the internet on how my students were able to do such things and somehow to let them feel that I also know the things that they are doing"

\subsubsection{Theme 5. Formulation of Criteria to Evaluate Class Outputs of Millennials}

Instructors should be creative enough in monitoring students' contributions and outputs to ensure that each plays a role. Instructors may grade students based on participation alone or by using rubrics that identify benchmarks for assessing both quantity and quality of each student's participation (Nevid, 2011).

"it is important that we make it clear to our students, the kind of project that we want them to submit to us"

\subsubsection{Theme 6. Imposing Sanctions for Late Submission and Bestowing Rewards for early submissions}

Rewards can be motivating to students to meaningfully engage in the learning process and without rewards it could be difficult for the teacher to instill the drive to students to achieve high levels of skills (Walberg and Bast, 2014). Giving rewards to students may improve their capability by guiding their attention to constructive action, reinforcing specific forms of learning and rewarding high levels of achievement Brophy (2008). The respondents have shared their small experiences of using rewards in engaging their students.

"they usually submit their requirements ahead of time, because I give them additional points for those projects that are submitted ahead of schedule, and it's always part of the rubric"

"during class orientation, I make it clear to the students that assignments are equivalent to $30 \%$ of their grades, so they really need to submit in order for them to pass, and failure to submit such requirements, I will not let them pass". 


\subsubsection{Theme 7. Requiring Hard and Soft Copies of Class Requirements}

"that's the danger that when you check the outputs of the students they have the same and identical outputs, so I usually require my students to submit both the soft copy and hard copy"

\subsubsection{Theme 8. Provision of Learner-Centered Activities in the Classroom}

Learning takes place only when different processes are activated, the goal of learner-centered teaching methods should facilitate this activation (Mykra, 2015). In the course of the learning process, the students may require re-motivation, reengagement and re-evaluation and the teachers should be ready to execute action steps as needed. The teacher respondents of this study have shared their own way of initiating a learner-centered activities in their respective classes.

"In my class, I let my students report, but we have a different way of reporting like I required them look for a video material. We watched the video and let the students explain, it's not boring and I don't talk much anymore".

"I required my students to come-up with a poster on Code of Ethics and then it was posted on Facebook and for them to "like" and "share" also video ads and it was a good output of my students"

According to Mykra (2015), the process requires gaining the attention of the students, informing the learners of the learning objectives, stimulating recall or prior learning, presenting the stimulus, providing learner guidance and eliciting performance, providing feedback and assessing performance.

\subsubsection{Theme 9. Validation of Internet Sources Used by the Millennials}

"students now are fond of doing the "copy-paste" from the internet, that's why teachers really must read the outputs of the students because there are lots of ways of copying like print screen, copy paste, because they know more techniques compared to what we know"

"like my problem solving exercise, the solution of the students was from the Facebook, they have a friend who is a foreigner and he was the one who discussed to them on how to solve the problem"

\section{Conclusion}

Mid-career teachers' struggles in teaching the millennials emanate from within themselves, from technology driven learning styles and strategies of the millennials and from deficient technology systems provided for as well as large millennial classes operated in the university.

Ways to cope by mid-career teachers in teaching millennial classes is foremost effected by establishing friendlier relations with the learners; putting more stringent evaluation criteria and systems on millennial class outputs into place and storing class requirements submissions of the learners well for the future use of mid-career teachers in the classroom.

Finally, policy implications that ought to be reckoned with to foster and promote effective millennial classrooms shall for the most part point to a paradigm shift from teacher-centeredness to leaner-centeredness with outcomes-based learning as ultimate goal in teaching inside the millennial classrooms. This in effect would entail the mid-career teachers undergoing capacity building programs along technology based computer assisted instruction to suit the technology savvy learning styles and strategies of millennial learners. Foremost, the building and establishment of efficient and effective technology system and technology infrastructure should be at the forefront relative to priorities of colleges and universities in this day and age of the millennial learners inside millennial classrooms in the Philippines and some parts of Asia. 


\section{References}

Bart, M (2011). The Five R's of Engaging Millennial Students. Faculty Focus Higher Ed Teaching Strategies. From https://www.facultyfocus.com/articles/teaching-and-learning/the-five-rs-of-engaging-millennial-students/

Beard, D. Schwieger, D., Surendran, K. (2007). Bridging the academic/industrial chasm for the millennial generation. Information Systems Education Journal. Vol. 5 No. 33

Benton, T. (2008) On stupidity: Part 2. The Chronicle of Higher Education Sept. 5th. Retrieved from https://www.chronicle.com/article/On-Stupidity-Part-2/45908

Brophy, J. (2008). Best Practice in Motivation and Management in the Classroom. Charles C. Thomas, Publisher, Ltd., second ed. Retrieved from http://www.americanthinker.com/articles/2014/07/ to_reward_or_not_to_reward_motivating_students_to_learn.html

Bruner, J. (1966). Toward a Theory of Instruction. Cambridgēe, MA: Harvard University Press.

Daniel, C. (2015). Should You Manage Millennial Teachers Differently? K12 HR Solutions. From http://www.k12hrsolutions.com/2015/09/22/should-you-manage-millennial-teachers-differently/

Davis M. H., (2003). Outcome-Based Education, Educational Strategies. Retrieved from http://www.utpjournals.com/jvme/tocs/303/258.pdf.

Division of Student Services. (2008). Meeting the Needs of Millennial Students. California State University. Retrieved from http://web.csulb.edu/divisions/students2/intouch/archives/2007-08/vol16_no1/01.htm

Flaherty, J. (2013). Millennial Students and Middle-aged Faculty: A Learner-centered Approach Toward Bridging the Gap. Faculty Focus Higher Ed Teaching Strategies. Retrieved from https://www.facultyfocus.com/articles/teaching-and-learning/millennial-students-and-middle-aged-facultya-learner-centered-approach-toward-bridging-the-gap/

Lester, S. (1999). An introduction to phenomenological research. Stan Lester Developments. From https://www.rgs.org/NR/rdonlyres/F50603E0-41AF-4B15-9C84-

BA7E4DE8CB4F/0/Seaweedphenomenologyresearch.pdf

McGlynn, A.P. (2005). Teaching Millennials, Our Newest Cultural Cohort. The Hispanic Outlook in Higher Education. Retrieved from http://www.hispanicoutlook.com.

Nevid, J.S. (2011). Teaching the Millennials. Association for Psychological Science.

Retrieved from https://www.psychologicalscience.org > Observer > 2011 > May/June

Nevid, J.S. (2008). In pursuit of the "perfect lecture." In B. Perlman, L.I. McCann, \& S.H. McFadden Eds, Lessons learned: Practical advice for the teaching of psychology (Vol. 3, pp. 181-188, Washington, DC: Association for Psychological Science.

Nocholas, A. 2008). Preferred Learning Methods of the Millennial Generation. Salve Regina University. Retrieved from http://digitalcommons.salve.edu/cgi/viewcontent.cgi?article=1017\&context=fac_staff_pub

Novotney, A. (2010). Engaging the Millennial Learner. American Psychological Association. Retrieved from http://www.apa.org/monitor/2010/03/undergraduates.aspx

Phillips, C.R. and Trainor, J.E. (2014). Millennial Students and the Flipped Classroom. St. John's University. Retrieved from http://asbbs.org/files/ASBBS2014/PDF/P/Phillips_Trainor(P519-530).pdf

Prensky, M. (2013). Digital natives, digital immigrants. In K. Blair, R. M. Murphy \& J. Almjeld (Eds.), Cross currents: Cultures, communities, technologies (pp. 45-51). Boston, MA: Cengage Learning.

Sanchez, S. (2016). The Millennial Learners, Changing the Way We Learn and Teach. Inside Higher Ed, University of Venus. Retrieved from https://www.insidehighered.com/blogs/university-venus/millenniallearners

Sandeen, C. (2008). Boomers, Xers, and Millennials: Who are they and what do they really want from continuing higher education? Continuing Higher Education Review, 72, 11- 31.

Spady W. G., (1994). Outcome-based education: Critical issues and answers. Arlington VA: American Association of School Administrators, Date retrieved: August 5, 2014

Stanford University (n.d.). Teaching the Millennial Generation Tomorrow's Teaching and Learning. Retrieved from https://tomprof.stanford.edu/posting/1047

Toothaker, R.D. (2014). A Phenomenological Study of Millennial Students and Traditional Pedagogies. University of Phoenix, ProQuest Dissertations Publishing. Retrieved from https://search.proquest.com/openview/9247dd91e36f77932b5217ec4efe688e/1?pqorigsite $=$ gscholar $\&$ cbl $=18750 \&$ diss $=y$

Van Manen, M. (2007). Phenomenology of Practice.Phenomenology \& Practice, Volume 1, No. 1, pp. 12. Available online: http://www.maxvanmanen.com/files/2011/04/2007-Phenomenology-of-Practice.pdf

Walberg, H.J. \& Bast, J.L. (2014). To Reward or Not to Reward: Motivating Students to Learn. The Heartland Institute. Retrieved from http://www.americanthinker.com/articles/2014/07/ to_reward_or_not_to_reward_motivating_students_to_learn.html 